\title{
Study of Suitable Washing Flowsheets For High Ash Coals of Nui Hong Coal Mine
}

\author{
Van Luan PHAM ${ }^{1, *}$, Ngoc Phu NGUYEN ${ }^{1)}$, Viet Ha LE ${ }^{1)}$
}

\footnotetext{
${ }^{1)}$ Hanoi University of mining and geology, Hanoi, Vietnam; email: phamvanluan@humg.edu.vn; nguyenngocphu@humg.edu.vn; levietha@humg.edu.vn
}

http://doi.org/10.29227/IM-2020-02-29

Submission date: 06-03-2020 | Review date: 22-09-2020

Abstract
Current high ash coal stockpile of Nui Hong Coal Mine is estimated at about 1 million tonnes. This increasingly stockpiled coal is not
sellable and disposable due to the government regulations so that a problem related to space and environment limitations becomes
more serious. This report presents the results of the study on washability of Nui Hong high ash coals and proposed suitable flowsheets
for washing this type of coals. Basic characteristics of the coals include High ash content of over 55\%; High moisture of above 20\%,
high rate of disintegration into finer particles in water, the high proportion of fine coals of the size fraction 0-6 mm; 30\% or more of
high ash superfine fraction -0.045 mm that contained mainly slime, clay and fine non-coal organic impurities. The results of particle
size analysis and sink-and-float analysis of $+1 \mathrm{~mm}$ coal sizes indicated that a $1-6 \mathrm{~mm}$ clean coal with ash content of less than $45 \%$
could be produced by a combination of coal feed crushing, washing and removal of 0-0.1 mm superfine particles. Flotation of the
size fraction - 0.1 mm could produce a clean coal float with the ash less than $40 \%$, provided that slimes should be removed before flo-
tation. From results of the study, it was found that the most suitable flowsheet for washing of Nui Hong high ash coals should include
crushing of the feed down to -6 (8) mm, washing by rotary scrubber screens to separate clean coal of 0.1-6 (8) mm, desliming of -0.1
mm fraction by spiral classifier before flotation. From the study samples with the average initial ash content of 55\%, a common clean
coal product with ash content of about $40-45 \%$ and with a yield of over $60 \%$ were obtained according to the proposed flowsheet. The
quality of the clean coal matched with Vietnam coal quality standard as $6 B$ grade fine coal (TCVN) so that it could be supplied to the
local thermal power plants.

Keywords: Nui Hong Coal Mine, high ash coal, washing, flotation

\section{Introduction}

Currently, coal thermal power is one of the major sources of electricity for the country. However, it is facing difficulties due to the shortage of coal supply. In 2019, the demand for coal for electricity generation was about 54.3 million tonnes while domestic coal mining could supply to the thermal power sector only about 36 million tonnes. It is forecasted that in the coming years, the shortage of coal for electricity generation will be more serious (vietnamnet.vn, 2019). Therefore, it is necessary to significantly increase domestic coal production. In this context, processing of substantial amounts of high ash coals stockpiled at mine sites may provide additional coals for the thermal power generation and may reduce the amount of expensive imported coal.

High ash coals or mixed coals are generated during the coal surface mining process. This type of coals is in fact intermediate layers of rocks and coals between the coal seams and their roofs and floors. Such high ash coals typically of very low grade with ash content of about $55-70 \%$ cannot be used or sold, particularly for coal thermal power plants, thus they are usually stored at temporary stockpiles at mine sites. The amount of accumulated high ash coals is continuously increased, at some mines it may reach over a million tones (Pham Van Luan \& Nguyen Ngoc Phu, 2014). This increases the pressure to the miners in both meanings of surface occupation, environment issues and loss of coal resources. Currently, most surface coal mines in Vietnam have coal washing plants for treating such high ash coals in order to recover additional clean coal for thermal power plants.

There are extensive experiences in the treatment of high ash coals at Quang Ninh area. Such experiences may be useful in finding solutions for Nui Hong high ash coals treatment. High ash coals of Quang Ninh area have low moisture content and low degree of degradation in the water environment. They are normally treated by gravity separation such as dense medium separation using magnetite as heavy solid or autogenous dense medium separation, conveyor belt washers and even air shaking tables (Nguyen Ngoc Tan, 2014; Phan Thi Thu Ha, 2014). Many coal mines in Quang Ninh utilize conveyor belt washers for separation of clean coals and waste rocks due to their simple structure, easy design and construction, easy operation and low production costs. Conveyor belt washers were proved relatively efficient for the size range of 6-35 (50) $\mathrm{mm}$. The existing conveyor belt washers of Quang Ninh, however, do not treat the size fraction of $-6 \mathrm{~mm}$. So this size fraction of coals is either discarded or used for blending as very low-quality fine coals. Another disadvantage of conveyor belt washers is that very high water consumptions of about 7-10 m3/tonne of feed create large amounts of coal pulps (Phạm Văn Luận \& Nguyen Ngoc Phu, 2014), which need to be treated to reduce the costs and reduce pollution of the surrounding environment.

Recently, air shaking tables were used at several surface coal mines such as Khanh Hoa, Mao Khe and Trang Khe mines. Air shaking tables were proved efficient for relative- 
Tab. 1. Particle size analysis of the sample

Tab. 1. Analiza wielkości cząstek w próbce

\begin{tabular}{|c|c|c|}
\hline Size fraction, $\mathbf{~ m m}$ & Yield, $\%$ & Ash content, $\%$ \\
\hline $\mathbf{1 0 0}$ & 26.4 & 50.68 \\
\hline $\mathbf{3 5}-\mathbf{1 0 0}$ & 8.15 & 48.68 \\
\hline $\mathbf{1 5 - 3 5}$ & 5.96 & 49.31 \\
\hline $\mathbf{6 - 1 5}$ & 4.72 & 45.05 \\
\hline $\mathbf{3 - \mathbf { 6 }}$ & 3.04 & 44.22 \\
\hline $\mathbf{1 - 3}$ & 3.3 & 41.24 \\
\hline $\mathbf{0 . 5 - 1}$ & 5.51 & 41.97 \\
\hline $\mathbf{0 . 2 - 0 . 5}$ & 0.5 & 41.27 \\
\hline $\mathbf{0 . 1 - 0 . 2}$ & 0.13 & 47.34 \\
\hline $\mathbf{0 . 0 7 4 - \mathbf { 0 . 1 }}$ & 4.36 & 42.98 \\
\hline $\mathbf{0 . 0 4 5 - 0 . 0 7 4}$ & 1.99 & 43.56 \\
\hline $\mathbf{- 0 . 0 4 5}$ & 35.94 & 55.28 \\
\hline Total & 100.00 & 50.31 \\
\hline
\end{tabular}

Tab. 2. Sink-and-float analysis of the sample size fractions

Tab. 2. Wyniki analiz densymetrycznych frakcji próbki

\begin{tabular}{|c|c|c|c|c|c|c|}
\hline \multirow{2}{*}{$\begin{array}{c}\text { Specific } \\
\text { gravity }\end{array}$} & \multicolumn{2}{|c|}{$\mathbf{1}-\mathbf{6 ~ m m}$} & \multicolumn{2}{c|}{$\mathbf{6 - 3 5} \mathbf{~ m m}$} & \multicolumn{2}{c|}{$\mathbf{3 5}-\mathbf{1 0 0}$ mm } \\
\cline { 2 - 7 } & Yield, \% & Ash content, \% & Yield, \% & Ash content, \% & Yield, \% & Ash content, \% \\
\hline $\mathbf{- 1 . 4}$ & 2.68 & 17.24 & 3.65 & 39.33 & 0.4 & 59.75 \\
\hline $\mathbf{1 . 4 - 1 . 5}$ & 12.46 & 9.45 & 4.87 & 20.67 & 1.53 & 18.76 \\
\hline $\mathbf{1 . 5} \mathbf{- 1 . 6}$ & 23.82 & 21.68 & 21.63 & 32.97 & 15.55 & 42.39 \\
\hline $\mathbf{1 . 6}-\mathbf{1 . 7}$ & 11.83 & 34.47 & 13.86 & 33.31 & 9.46 & 30.56 \\
\hline $\mathbf{1 . 7 - 1 . 8}$ & 6.78 & 45.44 & 6.93 & 48.12 & 7.16 & 33.23 \\
\hline $\mathbf{1 . 8} \mathbf{- 1 . 9}$ & 5.84 & 54.19 & 6.18 & 52.2 & 5.82 & 48.82 \\
\hline$+\mathbf{1 . 9}$ & 36.59 & 69.76 & 42.88 & 62.24 & 60.08 & 55.67 \\
\hline Total & 100 & 42.65 & 100 & 47.44 & 100 & 48.68 \\
\hline
\end{tabular}

Tab. 3. Particle size analysis of the crushed sample $-6 \mathrm{~mm}$

Tab. 3. Analiza wielkości cząstek rozdrobnionej próbki $-6 \mathrm{~mm}$

\begin{tabular}{|c|c|c|}
\hline $\begin{array}{c}\text { Size fraction, } \\
\text { mm }\end{array}$ & Yield, \% & $\begin{array}{c}\text { Ash content, } \\
\%\end{array}$ \\
\hline $\mathbf{3 - 6}$ & 14.08 & 47.54 \\
\hline $\mathbf{1 - 3}$ & 9.2 & 45.52 \\
\hline $\mathbf{0 . 5 - 1}$ & 9.95 & 43.4 \\
\hline $\mathbf{0 . 2 - 0 . 5}$ & 4.31 & 44.43 \\
\hline $\mathbf{0 . 1 - 0 . 2}$ & 1.13 & 48.22 \\
\hline $\mathbf{0 . 0 7 4 - 0 . 1}$ & 10.67 & 48.81 \\
\hline $\mathbf{0 . 0 4 5 - 0 . 0 7 4}$ & 6.3 & 50.57 \\
\hline $\mathbf{- 0 . 0 4 5}$ & 44.36 & 54.99 \\
\hline Total & 100 & 50.45 \\
\hline
\end{tabular}

ly dry coals in dry seasons but not efficient for damp coals, particularly in raining seasons which last from May to July. The dense medium separation was used at some surface coal mines such as Nui Beo, Ha Lam and Deo Nai mines. Dense medium separation may produce the highest quality of clean coals. However, it was not economically ideal for high ash coals due to high production costs and complexity of the washing technology. Both dense medium separation and air shaking tabling were gradually replaced by conveyor belt washing (Nguyen Thi Thanh, 2012; Nguyen Ngoc Tan, 2013).

Nui Hong coal mine in Thai Nguyen province is a surface coal mine, managed by Nui Hong Coal Company, a subsidiary of the Viet Bac Mining Industry Co. Coal seams of the mine are shallow, just below the rice field soil layers, so the mining conditions are favourable. The annual output of the mine is about 500,000 tonnes of run of mine low-rank coal. The coal of Nui Hong mine has different characteristics from anthracite coal of Quang Ninh area. According to Nguyen Ngoc Tan [Nguyen Ngọoc Tan, 2014], Nui Hong high ash coals have the basic the following characteristics: high moisture content of over $20 \%$, very high rate of disintegration in water, thus typically they contain over $60 \%$ of the size fraction $0-6 \mathrm{~mm}$ including $30 \%$ of slimes. According to this study, it is difficult to treat these high ash coals by gravity separation only. Therefore, flotation may be the additional alternative to cleanout this type of coals. However, conventional flotation technology only allows treating the size range of less than $0.5 \mathrm{~mm}$. In addition, high capital and production costs are the major disadvantages of conventional flotation technology. According to many works (Rick Q. Honaker, 2010; MD. Tariqul Islam and Anh V. Nguyen, 2019; J.N. Kuhmuench \& G.H. Luttrell, 2001; J.N. Kuhmuench \& Michael J. Mankosa et al., 2007, 2018; G.H. Luttrell \& T.C. Westerfield et al., 2006; Shadrack Fosu \& Bellson Awatey et al ., 2015; Bellson Awatey \& Homie Thanasekaran et al ., 2013; eriezflotation.com) HydroFloat separators may treat much coarser coal size than conventional fluidized bed separators. Thus it can be one of the alternatives worth to be explored for the treatment of Nui Hong high ash coals. The studies of Kohmuench and Michael J. Mankosa (J.N. Kuhmuench \& Michael J. Mankosa et al., 2007) have proved that HydroFloat separators are capable for washing of coal size up to $6 \mathrm{~mm}$ with actual combustible matter recovery of about $90 \%$. Therefore, HydroFloat separator was selected for the study of suitable flowsheets for washing of high ash coals of the Nui Hong mine.

\section{Material and method Samples}

The study samples were collected from the high ash coals dumpsite of Nui Hong mine. The samples were undergone wet 

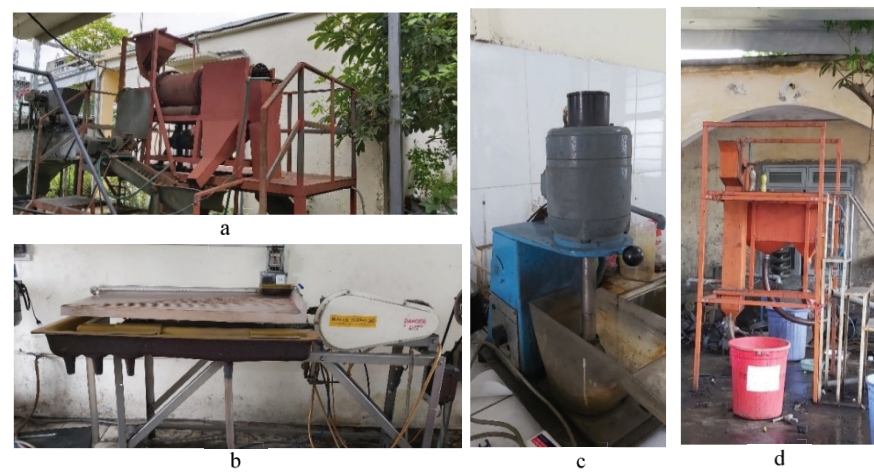

Fig. 1. The used study equipment a) Desliming system; b) Shaking table; c) Mechanical flotation cell; and d) Hydrofloat separator Rys. 1. Zużyty sprzęt badawczy: a) System redukcji szlamu; b) Stół do wytrząsania; c) mechaniczna komora flotacyjna; oraz d) separator Hydrofloat

Tab. 4. Sink-and-float analysis of the $1-6 \mathrm{~mm}$ size fraction of the crushed sample $-6 \mathrm{~mm}$ Tab. 4. Wyniki analiz ensymetrycznych frakcji wielkości $1-6 \mathrm{~mm}$ pokruszonej próbki - $6 \mathrm{~mm}$

\begin{tabular}{|c|c|c|c|c|}
\hline \multirow{2}{*}{$\begin{array}{l}\text { Specific gravity } \\
\text { fraction }\end{array}$} & \multicolumn{2}{|c|}{ Size fraction $1-6 \mathrm{~mm}$} & \multicolumn{2}{|c|}{ Cumulative float fraction } \\
\hline & Yield, \% & Ash content, \% & Yield, \% & Ash content, \% \\
\hline-1.4 & 2.88 & 20.32 & 2.88 & 20.32 \\
\hline $1.4-1.5$ & 19.04 & 11.34 & 21.92 & 12.52 \\
\hline $1.5-1.6$ & 12.79 & 19.06 & 34.71 & 14.93 \\
\hline $1.6-1.7$ & 6.7 & 27.75 & 41.41 & 17 \\
\hline $1.7-1.8$ & 5.96 & 32.37 & 47.37 & 18.94 \\
\hline $1.8-1.9$ & 7.61 & 56.89 & 54.98 & 24.19 \\
\hline+1.9 & 45.02 & 75.2 & 100 & 47.15 \\
\hline Total & 100 & 47.15 & & \\
\hline
\end{tabular}

Tab. 5. Proportion of the collector mixture

Tab. 5. Proporcja mieszanki kolektora

\begin{tabular}{|c|c|c|c|c|}
\hline Type of collector & Kerosene & Diezel & Berol & MIBC \\
\hline Proportion, \% & 35 & 20 & 30 & 15 \\
\hline
\end{tabular}

sieve analysis and float-and-sink analysis. The results of sample analyses are shown in Tables 1 and 2 .

Tables 1 and 2 show that the sample contained a substantial amount of slimes, clays and non-coal organic components as it contained up to $35.94 \%$ of $-0,045 \mathrm{~mm}$ size fraction with high ash content of $55.28 \%$. Coal of Specific Gravity (S.G.) fraction -1.4 had higher ash content than that of S.G. fraction 1.4-1.5 and an ash content of S.G. fractions - 1.4 increased with sizes.

For coarse size fractions $+6 \mathrm{~mm}$, there were higher percentages of high S.G. fraction +1.9 , and their average ash content was less than $60 \%$. It indicated that clean coal in these particle size ranges was so closely associated with gangue rock. This suggested that there should be a consideration for some kind of size reduction for the liberation of clean coal from gangue.

The two collected samples of $+6 \mathrm{~mm}$ were crushed, one down to below $-15 \mathrm{~mm}$ and the other down to below $-6 \mathrm{~mm}$ for comparison of the coal liberation degree. The crushed samples then were undergone the sink-and-float analyses to reveal liberation degrees of coals. The results of sink-andfloat analyses of the crushed samples showed that crushing of coals down to $-15 \mathrm{~mm}$ produced a low degree of liberation while crushing down to $-6 \mathrm{~mm}$ had a better liberation degree. Therefore, in this report, only the results of the coal crushing to $-6 \mathrm{~mm}$ is reported, as shown in Tables 3 and 4 .

After crushing the research sample down to below - $6 \mathrm{~mm}$, the yield of $-0.045 \mathrm{~mm}$ size fraction increased by about $10 \%$;
The ash content of S.G. fraction +1.9 significantly increased up to $75.2 \%$ (cf. Table 4 and Table 2), which indicated that a large amount of clean coal had been liberated from the gangue rock. Coal size range $1-6 \mathrm{~mm}$ may be treated by a number of gravity separators such as shaking tables, water only cyclone etc. (Andrew Falconer, 2003). In this study, a shaking table was selected for further research.

\section{Study equipment and research methods}

During the study process of Nui Hong high ash coals, the following equipment was used: A declining system consists of a rotary screen with diameter and length of 500x1000 mm and a single spiral classifier with major dimensions of 200x1000 mm (cf. Figure 1a); A shaking table with the table surface LxW of 1280x640 mm (cf. Figure 1b); A 3-litres mechanical flotation cell (cf. Figure 1c); A HydroFloat separator with 200x200 mm cross-section and $1200 \mathrm{~mm}$ height (cf. Figure 1d).

Each sample for a slime removal test and for a HydroFloat separation test had a weight of $50 \mathrm{~kg}$ while each sample for a shaking table test had a weight of $6 \mathrm{~kg}$. The experiments were carried out according to the traditional method, i.e., all parameters are fixed while the being surveyed parameter varied accordingly to the preplanned value ranges. The optimal parameters of the previous experiment were used for the next experiment.

Experimental results then were assessed through yield, ash content and actual combustible matter recovery in clean coal and waste products. 


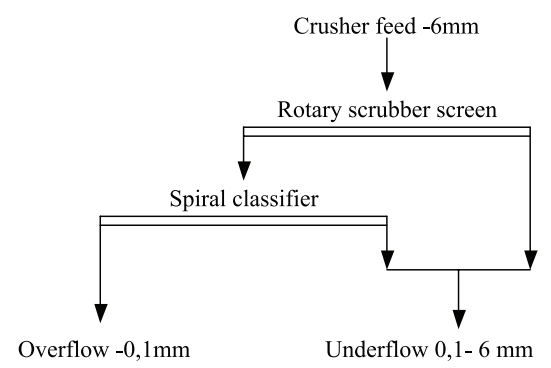

Fig. 2. Flowsheet for removal of slimes and clays Rys. 2. Proces usuwania mułów i glin

Tab. 6. Optimal technological regime of the desliming system

Tab. 6. Optymalny reżim technologiczny układu odwapniającego

\begin{tabular}{|l|c|l|c|}
\hline \multicolumn{2}{|c|}{ Rotary screen } & \multicolumn{2}{c|}{ Spiral classifier } \\
\hline Speed, rev/min. & 55 & Added water, $\boldsymbol{l} / \mathrm{kg}$ & 1 \\
\hline Water usage, $\boldsymbol{l} / \mathrm{kg}$ & 5 & Spigot wash water, $\boldsymbol{l} / \mathbf{k g}$ & 1.5 \\
\hline Water pressure, atm & 2 & & \\
\hline Feeding time, min. & 8 & & \\
\hline
\end{tabular}

Tab. 7. Experimental results of desliming system in the optimal regime Tab. 7. Wyniki eksperymentalne systemu odmulania w warunkach optymalnych

\begin{tabular}{|l|c|c|c|}
\hline Product & Yield, \% & Ash content, \% & Combustible matter recovery, \% \\
\hline Classifier overflow -0.1 mm & 66.47 & 53.46 & 62.51 \\
\hline Underflow 0.1 - 6 mm: & & & 0.72 \\
\hline - fraction $\mathbf{- 0 . 1} \mathbf{~ m m}$ & 0.77 & 53.62 & 36.77 \\
\hline - fraction $+\mathbf{0 . 1} \mathbf{~ m m}$ & 32.76 & 44.47 & $\mathbf{3 7 . 4 9}$ \\
\hline Total underflow $\mathbf{0 . 1}-\mathbf{6} \mathbf{~ m m}$ & $\mathbf{3 3 . 5 3}$ & $\mathbf{4 4 . 6 8}$ & $\mathbf{1 0 0 . 0 0}$ \\
\hline Total & $\mathbf{1 0 0}$ & $\mathbf{5 0 . 5 2}$ & \\
\hline
\end{tabular}

Tab. 8. Size distribution of the deslimed classifier overflow sample Tab. 8. Rozkład wielkości próbki przepełnienia odszlamionego klasyfikatora

\begin{tabular}{|l|c|c|}
\hline Product & Yield, \% & Ash content, \% \\
\hline $\mathbf{0 . 0 4 5}-\mathbf{0 . 1} \mathbf{~ m m}$ & 40.99 & 51.38 \\
\hline $\mathbf{0 - 0 . 4 5} \mathbf{~ m m}$ & 25.48 & 56.44 \\
\hline Total & $\mathbf{6 6 . 4 7}$ & $\mathbf{5 3 . 3 2}$ \\
\hline
\end{tabular}

\section{Reagents}

Coal has a natural hydrophobicity. However, for efficient flotation of coals collectors such as kerosene, diesel oil, fuel oil, etc. Should be used. The collecting power of a non-ionic collector is proportional with the length of the hydrocarbon radical while the collector selectivity is in reverse. Therefore, using a mixture of collectors of different hydrocarbons always give higher efficiency than a single hydrocarbon collector (Nguyễn Hoàng Sơn, 2019; Janusz S. Laskowski, 2001). In order to increase the efficiency of coal flotation, many studies have attempted mixing a number of ionic with non-ionic collectors (Renhe Jia, Guy H. Harris, Douglas W. Fuerstenau, 2002; Dube and Raghav M, 2012). In this study, mixtures of an ionic collector (Berol of the former Akzo Nobel) with kerosene and diesel were used. For flotation of the Nui Hong high ash coals, mixtures of selected collectors with several mixing ratios were explored by the research team. The best proportion was chosen for further flotation experiments. Here, only the best mixture proportion is presented, as shown in Table 5 .

\section{Slime removal system}

Nui Hong high ash coals were sticky due to high slime and clay content. Therefore, it is necessary to use a rotary screen to disintegrate the clay and slimes from coals before separation stage in HydroFloat separator or shaking table. About $50 \mathrm{~kg}$ of the crushed sample below - $6 \mathrm{~mm}$ were deslimed according to the flowsheet, as shown in Figure 2. Optimal technological variables of the desliming system were evaluated through the amount of $-0.1 \mathrm{~mm}$ size fraction in $0.1-6 \mathrm{~mm}$ product. These variables and the test results in the optimal regime are shown in Tables 6 and 7.

The sliming rate of the size fraction $0.1-6 \mathrm{~mm}$ in the rotary screen was about $15 \%$ as the fraction yield reduced from $38.67 \%$ (cf. Table 3 ) to $32.76 \%$ and the ash content reduced from $45.67 \%$ down to $44.47 \%$. It indicated that the debris contains mainly humus and non-coal material.

\section{Study on treatment of classifier overflow 0-0.1 mm}

The classifier overflow product of the size fraction $0-0.1$ $\mathrm{mm}$ was divided into two identical parts. One part was preliminarily deslimed so that it consisted predominantly from size fraction $0.045-0.1 \mathrm{~mm}$ (cf. Table 8 ) while the other part left without slime removal. These two samples were subjects for flotation by a 3-litre mechanical flotation cell at several technological regimes for comparison the effect of slimes on flotation performance. Flotation results of the above two samples at a solid concentration of $250 \mathrm{~g} / \mathrm{l}$, and the collector dosage of $2.2 \mathrm{~kg} /$ ton are shown in Table 9.

Table 9 shows that flotation of the deslimed sample produced higher quality products in comparison to the flotation 
Tab. 9. Flotation results of the 02 overflow samples at identical flotation regime

Tab. 9. Wyniki flotacji próbek z przelewu 02 przy identycznym reżimie flotacji

\begin{tabular}{|l|c|c|c|c|}
\hline \multirow{2}{*}{ Product } & \multicolumn{2}{|c|}{ Non-deslimed sample 0- 0.1 mm } & \multicolumn{2}{c|}{ Deslimed sample 0.045- 0.1 mm } \\
\cline { 2 - 5 } & Yield, \% & Ash content, \% & Yield, \% & Ash content, \% \\
\hline Clean coal & 35.99 & 43.14 & 29.82 & 41.18 \\
\hline Reject & 30.48 & 63.12 & 11.17 & 78.62 \\
\hline Total & $\mathbf{6 6 . 4 7}$ & $\mathbf{5 2 . 3}$ & $\mathbf{4 0 . 9 9}$ & $\mathbf{5 1 . 3 8}$ \\
\hline
\end{tabular}

Tab. 10. Coal feed sample of the HydroFloat separator

Tab. 10. Próbka surowca węglowego do separatora HydroFloat

\begin{tabular}{|l|c|c|}
\hline Size fraction, $\mathbf{~ m m}$ & Yield, \% & Ash content, \% \\
\hline $\mathbf{0 . 0 4 5}-\mathbf{1}$ & 49.47 & 50.72 \\
\hline $\mathbf{1}-\mathbf{6}$ & 25.05 & 44.75 \\
\hline
\end{tabular}

Tab. 11. Optimal technological regime of HydroFloat separator for each size fraction

Tab. 11. Optymalny reżim technologiczny separatora HydroFloat dla każdej frakcji wymiarowej

\begin{tabular}{|c|c|c|c|}
\hline Regime & $\begin{array}{lr}\text { Size } & \text { fraction } \\
0.045 & -0.1 \mathrm{~mm} \\
\end{array}$ & $\begin{array}{l}\text { Size fraction } \\
0.045-1 \mathrm{~mm} \\
\end{array}$ & $\begin{array}{l}\text { Size fraction } 1- \\
6 \mathrm{~mm}\end{array}$ \\
\hline Fluidizing water flow rate, $l / \mathrm{min}$. & 70 & 100 & 140 \\
\hline Feeding time, min. & 5 & 5 & 5 \\
\hline Collector dosage, $\mathrm{kg} / \mathrm{t}$ & 3.3 & 4 & 4.5 \\
\hline Added MIBC, g/m $\mathrm{m}^{3}$ water & 40 & 40 & 40 \\
\hline Air flowrate, $l / \mathrm{min}$. & 300 & 300 & 300 \\
\hline
\end{tabular}
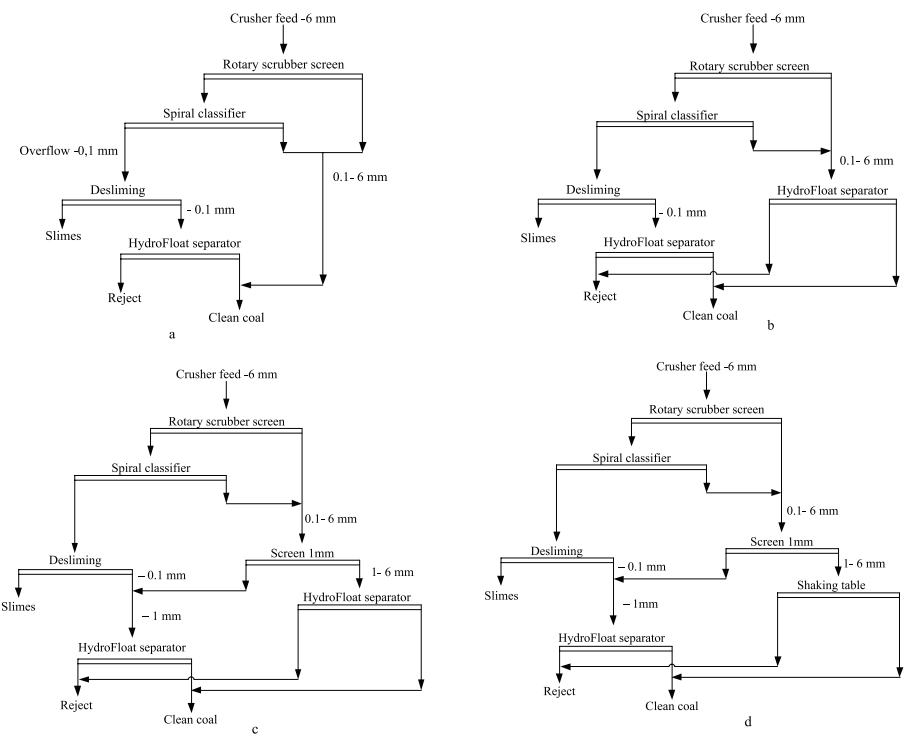

Fig. 3. Alternative flowsheets for treatment of crushed high ash coals $-6 \mathrm{~mm}$

Rys. 3. Alternatywny schemat technologiczny do obróbki rozdrobnionych węgli wysokopopiołowych $-6 \mathrm{~mm}$

of the non-deslimed sample. The clean coal ash content was lower by about $2 \%$ while the ash content of the reject was higher by about $15.5 \%$. The high ash content of the reject made it eligible for disposal. Lower clean coal yield of the deslimed sample flotation by about $6 \%$ might be caused by significant entrainment effect and also by flotation of more superfine coal particles. It suggested that slimes had significant adverse effects on the flotation performance of the Nui Hong high ash coals. Reduction of the slime content of the feed pulps to the flotation made the flotation process much easier due to less entrainment, less collector dosage and as a consequence easier dewatering of clean coals. Thus preliminary desliming of the feed pulps should be performed prior to flotation.

\section{Proposed flowsheet for coal recovery}

In order to determine suitable flowsheets for Nui Hong high ash coals, four alternative flowsheets were chosen for experiments, as shown in Figure 3.

Option 1: Flotation of particle size fraction of $0.045-0.1$ $\mathrm{mm}$ by HydroFloat separator but the size fraction $+0.1 \mathrm{~mm}$ left untreated and considered for mixing with clean coal (cf. Figure 3a);

Option 2: Flotation of both size fractions of $0.045-0.1$ $\mathrm{mm}$ and $0.1-6 \mathrm{~mm}$ by HydroFloat separator (cf. Figure $3 \mathrm{~b}$ );

Option 3: Flotation of both size fractions of $0.045-1 \mathrm{~mm}$ and $1-6 \mathrm{~mm}$ by HydroFloat separator (cf. Figure 3c);

Option 4: Flotation of the size fraction of $0.045-1 \mathrm{~mm}$ by HydroFloat separator. The fraction $1-6 \mathrm{~mm}$ treated by shaking table (cf. Figure 3d). 
Tab. 12. Treatment performance results according to Option 1 (cf. Figure 3a)

Tab. 12. Wyniki przetwarzania według Opcji 1 (por. Rysunek 3a)

\begin{tabular}{|l|c|c|c|}
\hline Operation & Product & Yield, \% & Ash content, \% \\
\hline \multirow{2}{*}{\begin{tabular}{l} 
HydroFloat fraction $\mathbf{0 . 1} \mathbf{~ m m}$ \\
\cline { 2 - 4 }
\end{tabular}} & Clean coal & 27.3 & 38.65 \\
\cline { 2 - 4 } & Reject & 13.69 & 76.67 \\
\hline Fraction 0.1 -6 mm & Sum & $\mathbf{4 0 . 9 9}$ & $\mathbf{5 1 . 3 5}$ \\
\hline Slimes & 33.53 & 44.68 \\
\hline Total clean coal & 25.48 & 56.44 \\
\hline Reject & $\mathbf{6 0 . 8 3}$ & $\mathbf{4 1 . 9 7}$ \\
\hline Total & 13.69 & 76.67 \\
\hline
\end{tabular}

Tab.13. Treatment performance results according to Option 2 (cf. Figure 3b) Tab.13. Wyniki przetwarzenia według Opcji 2 (por. Rysunek 3b)

\begin{tabular}{|c|c|c|c|}
\hline Operation & Product & Yield, \% & Ash content, $\%$ \\
\hline \multirow{3}{*}{$\begin{array}{l}\text { HydroFloat fraction } \\
0.045-0.1 \mathrm{~mm}\end{array}$} & Clean coal & 27.3 & 38.65 \\
\hline & Reject & 13.69 & 76.67 \\
\hline & Sum & 40.99 & 51.35 \\
\hline \multirow{3}{*}{$\begin{array}{l}\text { HydroFloat fraction } 0.1 \\
-6 \mathrm{~mm}\end{array}$} & Clean coal & 24.06 & 39.47 \\
\hline & Reject & 9.47 & 60.83 \\
\hline & Sum & 33.53 & 45.5 \\
\hline \multicolumn{2}{|l|}{ Slimes } & 25.48 & 56.44 \\
\hline \multicolumn{2}{|l|}{ Total clean coal } & 51.36 & 39.03 \\
\hline \multicolumn{2}{|l|}{ Total reject } & 23.16 & 70.19 \\
\hline \multicolumn{2}{|l|}{ Total } & 100 & 50.68 \\
\hline
\end{tabular}

Tab. 14. Treatment performance results according to Option 3 (cf. Figure 3c) Tab. 14. Wyniki przetwarzenia według Opcji 3 (por. Rysunek 3c)

\begin{tabular}{|l|l|c|c|}
\hline Operation & Product & Yield, \% & Ash content, \% \\
\hline \multirow{2}{*}{$\begin{array}{l}\text { HydroFloat fraction } \\
\mathbf{0 . 0 4 5}-\mathbf{1 m m}\end{array}$} & Clean coal & 32.81 & 40.78 \\
\cline { 2 - 4 } & Reject & 16.66 & 70.32 \\
\cline { 2 - 4 } & Sum & 49.47 & $\mathbf{5 0 . 7 3}$ \\
\hline \multirow{2}{*}{$\begin{array}{l}\text { HydroFloat fraction 1 } \\
\mathbf{6 m m}\end{array}$} & Clean coal & 16.56 & 37.82 \\
\cline { 2 - 4 } & Reject & 8.49 & 58.21 \\
\cline { 2 - 4 } & Sum & $\mathbf{2 5 . 0 5}$ & 44.73 \\
\hline Slimes -0.045 & 25.48 & 56.44 \\
\hline Total clean coal & $\mathbf{4 9 . 3 7}$ & $\mathbf{3 9 . 7 9}$ \\
\hline Total reject & $\mathbf{2 5 . 1 5}$ & $\mathbf{6 6 . 2 3}$ \\
\hline Total & $\mathbf{1 0 0}$ & $\mathbf{5 0 . 6 8}$ \\
\hline
\end{tabular}

Tab. 15. Treatment performance results according to Option 4 (cf. Figure 3d) Tab. 15. Wyniki przetwarzenia zgodnie z Opcją 4 (por. Rysunek 3d)

\begin{tabular}{|c|c|c|c|}
\hline Operation & Product & Yield, \% & Ash content, \% \\
\hline \multirow{3}{*}{$\begin{array}{l}\text { HydroFloat fraction } \\
0.045-1 \mathrm{~mm}\end{array}$} & Clean coal & 32.81 & 40.78 \\
\hline & Reject & 16.66 & 70.32 \\
\hline & Sum & 49.47 & 50.73 \\
\hline \multirow{3}{*}{$\begin{array}{l}\text { Shaking table fraction } \\
1-6 \mathrm{~mm}\end{array}$} & Clean coal & 17.23 & 38.51 \\
\hline & Reject & 7.82 & 58.53 \\
\hline & Sum & 25.05 & 44.76 \\
\hline \multicolumn{2}{|l|}{ Slimes $-0.045 \mathrm{~mm}$} & 25.48 & 56.44 \\
\hline \multicolumn{2}{|l|}{ Total clean coal } & 50.04 & 40 \\
\hline \multicolumn{2}{|l|}{ Total reject } & 24.48 & 66.55 \\
\hline \multicolumn{2}{|l|}{ Total } & 100 & 50.69 \\
\hline
\end{tabular}

In order to prepare the size fraction $1-6 \mathrm{~mm}$ for feeding to the HydroFloat separator, the classifier underflow with the size fraction $0.1-6 \mathrm{~mm}$ (cf. Table 7) was screened by a sieve with $1 \mathrm{~mm}$ aperture opening to obtain the oversize with the desired size 1-6 $\mathrm{mm}$. The undersize $-1 \mathrm{~mm}$ fraction of the sieve was mixed with the deslimed classifier overflow to obtain the desired size fraction $0.045-0.1 \mathrm{~mm}$ for feeding of the HydroFloat separator. The specific yields and ash contents of these two feed samples to the Hydrofloat separator are shown in Table 10. Optimal technological variables of HydroFloat separator for each size fractions are shown in Table 11. Experimental results for each option are shown in Tables 12, 13, 14 and 15.
Option 1 produced the highest clean coal yield of $60.83 \%$, but with the lowest quality (ash content reached 41.97\%). As for other options, clean coal yields were around $50 \%$, but the quality of clean coals had not been much improved as their ash varied from 39 to $40 \%$;

The size fraction of $0.045-0.1 \mathrm{~mm}$ had the best results on the HydroFloat separator with the lowest collector dosage and fluidizing water flowrate;

The flotation efficiencies of mechanical flotation machine and HydroFloat separator for the size fractions of 1-6 mm and 0.1-6 mm were not much different. HydroFloat separator required higher collector dosage (with $3.3 \mathrm{~kg} /$ tonne vs $2.2 \mathrm{~kg} /$ tonne of mechanical one), required additional 
frother (MIBC) with a dosage of about $40 \mathrm{~g} / \mathrm{m} 3$ of fluidizing water.

The flotation efficiencies of HydroFloat separator for the size fraction $1-6 \mathrm{~mm}$ and of the shaking table for the size fraction $0.1-6 \mathrm{~mm}$ were both low, the waste rock products obtained had low ash content ranging between $58-61 \%$. This may be due to the fact that at all density fractions evenly distributed in all size fractions, making it difficult to separate;

Further increase in fluidizing water flowrate may produce the required quality of waste rock, however, more fine particles of high density misplaced into clean coal products, reducing their quality;

From the research results, option one should be chosen for the treatment of the Nui Hong high ash coals. This option allows for obtaining clean coal products of satisfactory quality for thermal power plants of Vietnam. At the same time, there is a greater amount of clean coals, lower operating costs and simpler treatment technology.

\section{Conclusion}

Nui Hong high ash coals or mixed coals have specific features including high slimes and clay content, high moisture content, high disintegration in water and low floatability and low washability;

From the research results, it is found that Option 1 is the most suitable option for the treatment of the Nui Hong high ash coals. However, it is recommended that the raw high ash coals should be firstly washed for removal of virgin slimes and clays before crushing to $-6 \mathrm{~mm}$, then flowsheet, as shown in Figure 3.a, can be applied;

By applying the option 1, the treatment of Nui Hong high ash coals should produce clean coal product with yield, ash and combustible recovery of $60.83 \% ; 41.97 \%$ and $71.18 \%$ respectively. Clean coal should be equivalent to a $6 \mathrm{~B}$ grade of fine coals (TCVN) suitable for supply to thermal power plants;

For flotation of fine coal pulp of $0.045-0.1 \mathrm{~mm}$, it is possible to use various types of column flotation machines, however, in the case of Nui Hong high ash coals, mechanical flotation machines are more suitable due to their lesser capacity and lesser investment costs.

\section{Literatura - References}

1. T. THANH NGUYEN. Study on coal cleaning performance by air shaking table - Trang Khe Vinacomin coal preparation plant. Master degree dissertation, Ha noi University of mining and geology. 2012. (in Vietnamese).

2. NGOC TAN NGUYEN. Assesment of current coal preparation technologies and proposal of some technological solutions in order to improve the coaruse coal preparation production line at Uong Thuong processing site of Uong Bi Coal Co., Master degree dissertation, Ha noi University of mining and geology. 2013. (in Vietnamese).

3. NGOC TAN NGUYEN. Study on technolgy for recovery of clean coals from small coals, screen rejects and mixed coal in order to maximize recovery of mineral resource of Khanh Hoa and Nui Hong coal mines. Institute for mining science and technology. project report. 2014. (in Vietnamese).

4. T.T HA PHAN. Study on cleaning of low grade coals of Vang Danh - Uong Bi area by conveyor belt separator and fluidized bed separator, Master degree dissertation, Ha noi University of mining and geology. 2014. (in Vietnamese).

5. VAN LUAN PHAM; NGOC PHU NGUYEN. Study on cleaning of low grade coals of Vang Danh - Uong Bi area by conveyor belt separator. Mining Industry journal. 2014, No. 3, p. 26-28. ISSN 0868-7052. (in Vietnamese).

6. HOANG SON NGUYEN. Study on cleaning of fine coals 0,5-8mm of Vang Danh - Uong Bi area by HydroFloat separator with capacity of 1 tonne per hour. Mineral processing Association of Vietnam. project report. 2019. (in Vietnamese).

7. JANUSZ S. LASKOWSKI. Coal Flotation and Fine Coal Utilization. Elsevier. 2001. ISBN: 0-444-50537-7

8. RENHE JIA, GUY H. HARRIS, DOUGLAS W. FUERSTENAU. Chemical Reagents for Enhanced Coal Flotation. Coal Preparation.2002, Vol. 22, p. 123-149. ISSN: 1939-2699 
9. DUBE, RAGHAV M. Collectors for enabling flotation of oxidized coal. Theses and Dissertations-Mining Engineering, University of Kentucky. 2012.

10. RICK Q. HONAKER. International Coal Preparation Congress 2010 conference proceedings, Society for Mining, Metallurgy and Exploration. 2010, p. 421 - 431. ISBN: 978-0-87335-332-8.

11. MD. TARIQUL ISLAM, ANH V. NGUYEN.A numerical study with experimental validation of liquid-assisted fluidization of particle suspensions in a HydroFloat cell,Minerals Engineering. 2019, Vol.134, p. 176 - 192. ISSN: 0892-6875.

12. J.N. KOHMUENCH AND G.H. LUTTRELL.Coarse particle concentration using the HydroFloat Separator.Minerals \& Metallurgical processing. 2001, Vol .18, No. 2, p. 61 - 67. ISSN: 2524-3470.

13. J.N. KOHMUENCH AND M.J. MANKOSA, D.G. KENNEDY, J.L. VASALONIS AND G.B. TAYLOR, G.H. LUTTRELL.Implementation of the HydroFloat technology at the South Fort Meade Mine.Minerals \& Metallurgical Processing. 2007, Vol. 24, No. 4, p. 264 - 270. ISSN: 2524-3470.

14. J.N. KOHMUENCH, M.J. MANKOSA, H. THANASEKARAN, A. HOBERT.Improving coarse particle flotation using the HydroFloat ${ }^{\text {tw }}$ (raising the trunk of the elephant curve).Minerals Engineering . 2018, Vol. 121, pg. 137 - 145. ISSN: 0892-6875.

15. G H LUTTRELL, T C WESTERFIELD, J N KOHMUENCH, M J MANKOSA.Development of high-efficiency hydraulic separators.Minerals \& Metallurgical Processing. 2006,Vol. 23, No. 1, p. 33 - 39. ISSN: 2524-3470.

16. SHADRACK FOSU, BELLSON AWATEY, WILLIAM SKINNER, MASSIMILIANO ZANIN.Flotation of coarse composite particles in mechanical cell vs. the fluidized-bed separator (The HydroFloat ${ }^{\mathrm{su}}$ ). Minerals Engineering. 2015,Vol. 77, p. 137 - 149. ISSN: 0892-6875.

17. BELLSON AWATEY, HOMIE THANASEKARAN, JAISEN N. KOHMUENCH, WILLIAM SKINNER, MASSIMILIANO ZANIN. Optimization of operating parameters for coarse sphalerite flotation in the HydroFloat fluidized-bed separator. Minerals Engineering. 2013,Vol. 50 - 51, pg 99 - 105. ISSN: 0892-6875.

18. ANDREW FALCONER. Gravity separation: Old technique/new methods. Physical Separation in Science and Engineering. 2003, Vol. 12, No. 1, pp. 31-48.ISSN 1478-6478.

19. https://vietnamnet.vn/vn/kinh-doanh/dau-tu/thieu-chuc-trieu-tan-than-cho-nhiet-dien-551698.html.

20. https://www.eriezflotation.com/flotation/hydrofloat-flotation/.

\section{Badanie odpowiednich schematów technologicznych płukania węli wysokopopiołowych w kopalni Nui Hong}

Obecne zapasy węgla o wysokiej zawartości popiołu w kopalni Nui Hong szacuje się na około $1 \mathrm{mln}$ ton. Ten coraz bardziej gromadzony wegiel nie nadaje się do sprzedaży ani do utylizacji, przez co problem związany z zanieczyszczeniem środowiska staje się coraz poważniejszy. W artykule, przedstawiono wyniki badań nad zmywalnością węgli wysokopopiołowych Nui Hong oraz zaproponowano odpowiedni proces do mycia tego typu węgli. Podstawowe cechy wegli to: wysoka zawartość popiołu powyżej 55\%; wysoka wilgotność powyżej 20\%, duża szybkość rozpadu na drobne cząstki w wodzie, duży udział drobnych wegli o frakcji wymiarowej 0 - 6 $\mathrm{mm} ; 30 \%$ lub więcej bardzo drobnej frakcji o wysokiej zawartości popiołu - 0,045 mm, która zawierała głównie szlam, glinę i drobne zanieczyszczenia organiczne niewęglowe. Wyniki analiz wielkości czastek i analizy typu densymetrycznych o wielkościach węla +1 mm tego czystego węgla 1-6 mm z zawartościa popiołu poniżej 45\% można uzyskać przez połaczenie kruszenia, przemywania i usuwania wsadu weglowego 0 - 0,1 mm bardzo drobnych cząstek. Flotacja frakcji wymiarowej - 0,1 mm mogłaby dać czysty pływak węglowy o zawartości popiołu poniżej 40\%, pod warunkiem, że szlam powinien zostać usunięty przed flotacją. Na podstawie wyników badań stwierdzono, że najbardziej odpowiednim schematem technologicznym do przemywania wegli wysokopopiołowych Nui Hong powinno być kruszenie nadawy do -6 (8) mm, przemywanie przez płuczki obrotowe w celu oddzielenia czystego węla o zawartości 0,1- $6 \mathrm{~mm}$. (8) mm, odmulanie frakcji-0,1 $\mathrm{mm}$ za pomoca spiralnego klasyfikatora przed flotacją. Z próbek badawczych o średniej początkowej zawartości popiołu 55\%, zgodnie z proponowanym schematem technologicznym uzyskano pospolity czysty produkt węglowy o zawartości popiołu około 40 - 45\% i uzysku powyżej 60\%. Jakość czystego węgla odpowiadała wietnamskiemu standardowi jakości wegla jako miał węglowy klasy $6 B(T C V N)$, tak aby mógł być dostarczany do lokalnych elektrociepłowni.

Słowa kluczowe: kopalnia węgla Nui Hong, węgiel wysokopopiołowy, płukanie, flotacja 